\title{
NOISE ASPECTS ON CARGO SHIPS IN THE CONTEXT OF DANUBE NAVIGATION
}

\author{
Professor Habil., PhD, MIHAELA PICU \\ Interdisciplinary Regional Research Laboratory \\ in Vibro-Acoustic Pollution \\ and Environmental Quality \\ Faculty of Engineering and Agronomy Braila, \\ "Dunarea de Jos" University of Galati
}

\begin{abstract}
This paper analysed the noise from a pusher ship on the Danube. The measurements were made according to "Ship Vibration and Noise Guidance Notes". The analysis was performed on a pusher ship (2400HP), with 6 barges, moving upstream, from Sulina ( $\mathrm{km} \mathrm{0)}$ to Bazias ( $\mathrm{km} \mathrm{1072).}$ The noise was measured with BlueSolo01dB type sound meter, placed in the engine room, the main deck and the rest room. So, in the first case, inside the engine room, the Daily noise exposure $\left(L_{E P, d}\right)$ was $92 \mathrm{~dB}$; in the second case,on the main deck, $L_{E P, d}$ was $88 \mathrm{~dB}$ and in the third case, inside the rest room, $L_{E P, d}$ was $83 d B$. For the entire week $L_{E P, w}$ was $92 \mathrm{~dB}$. It can seen that (for the noise over the entire duration of the trip) the Lower Exposure Action Value $\left(L_{E P, d}=80 \mathrm{~dB}\right.$ given by Directive 2003/10/EC) is exceeded by $15 \%$ and the Upper Exposure Action Value (85dB) by $8.23 \%$. For this reason, hearing protectors are recommended.
\end{abstract}

KEYWORDS: meteorological parameters, Daily Noise exposure, Weekly Noise exposure, pusher ship, the Danube

\section{INTRODUCTION}

On the Danube river there are a lot of commercial ships that travel upstream and downstream, under the flags of different countries. One of the problems that are little discussed in the specialized literature is that of the crew comfort on these ships. An essential part of this comfort is the noise generated by the equipment on the ship. This aspect was little studied [1-3].

Also, the weather conditions greatly contribute to the comfort of the crew members, influencing their ability to work.

In this paper, the meteorological parameters and the noise from one pusher ship on the Danube were analyzed.

The measurements were made according to "Ship Vibration and Noise Guidance Notes", Section 8 (Noise), Lloyd's Register, 2006 [4] and „Guidance Notes General Overview of Ship
Structural Vibration and Noise Problems", Lloyd's Register, September 2015 [5].

"According to Table 8.2 Measuring positions [4]: At least one measurement in every occupied space in the center of the room with doors and windows closed. If noise level varies throughout space, then extra readings at $7 \mathrm{~m}$ intervals including the position of maximum noise should be taken.

- Wheelhouse: One extra reading at an open window.

- Bridge wings: At control positions on both wings when on leeside of wind.

- Radio room: In centre and at work position.

- Galley/pantry: With equipment not working and at $1 \mathrm{~m}$ away from the working equipment.

Ship's whistle: Measured at listening posts (bridge wings, forecastle). 
For machinery spaces, the measuring position is usually at $1 \mathrm{~m}$ from engine and at intervals not greater than $3 \mathrm{~m}$ around machinery.

- Large engine rooms: if readings at $3 \mathrm{~m}$ intervals do not vary much, then four measurements on each level.

Spaces: machinery and cargo control rooms, workshops, stores, fan rooms, pump rooms, refrigerator rooms, steering gear rooms, access routes.

Machinery: engines at each level and local control stations, main gearing, turbo-blowers, purifiers, alternators, firing platforms, fans, compressors, cargo pumps.

Machines under $5 \mathrm{~kW}$ may be excluded unless significant noise sources."

According to Table 8.3 [4], "The acceptable maximum noise levels for crew are:

For working areas: radio room (equipment working, but no audio signals) $60 \mathrm{dBA}$, wheelhouse, chartroom $65 \mathrm{dBA}$, listening post, including bridge wings and windows $70 \mathrm{dBA}$, galleys, pantries and serveries (equipment not working) 75dBA, machinery control rooms $75 \mathrm{dBA}$, workshops $85 \mathrm{dBA}$, normally unoccupied spaces, e.g. holds, decks 90dBA, machinery space, continuously manned, e.g. stores 90dBA Machinery space, not continuously manned, e.g. pump, refrigerator, thruster or fan rooms $110 \mathrm{dBA}$.

For accommodation spaces: hospitals and sleeping cabins - 60dBA, day cabins - 65dBA, offices and conference rooms - 65dBA, recreation areas within the accommodation, mess rooms, lounges $-65 \mathrm{dBA}$, recreation areas on open deck - 75dBA, alleyways, bathrooms, changing rooms, lockers - 80dBA, Ship's whistle - 110dBA (at bridge wings or forecastle).

- When the noise level exceeds 85dBA, hearing protection is required."

\section{MATERIALS AND METHODS}

At Bazias, the Danube river enters Romania (from Serbia) and forms a natural border with Bulgaria, up to Silistra. From here to Giurgiulești, the Danube is only on the territory of Romania, then it forms a natural border with Ukraine. The Danube flows into the Black Sea, having travelled a distance of $1072 \mathrm{~km}$ on the Romanian territory.

The analysis was performed on a pusher ship (2400HP), with 6 barges, moving upstream, from Sulina $(\mathrm{km} \mathrm{0)}$ to Bazias $(\mathrm{km}$ 1072), in July 2018. This trip was made in 7 days (24/24), thus: day 1 was intended for loading and fastening the goods, day 2: Sulina Harsova; day 3: Harsova - Giurgiu; day 4: Giurgiu - Bechet; day 5: Bechet - Gruia; day 6: Gruia - Bazias (fig. 1). The ship continued its way to Budapest. The speed of the ship varied between $8-10 \mathrm{~km} / \mathrm{h}$ and the speed of the Danube between $3-4 \mathrm{~km} / \mathrm{h}$.

The weather conditions are shown in fig. 2. The meteorological parameters were also measured on board with Kestrel 5500 Weather Meters (this device measures wind speed and direction, temperature, humidity, pressure, etc.); the meteorogram was provided by Baneasa weather station. 


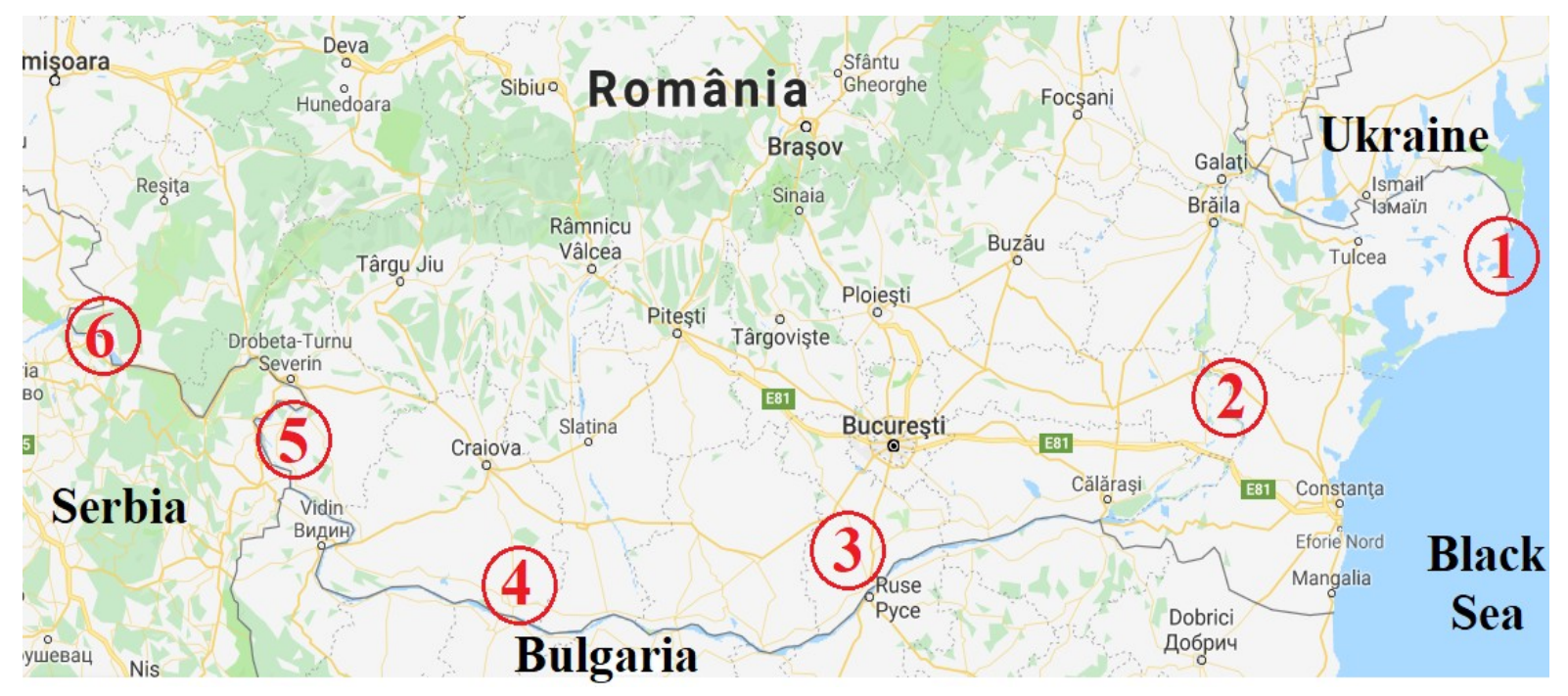

Figure 1. The main cities crossed by the ship, each day of the trip

(1) - Sulina ( $\mathrm{km} \mathrm{0);} \mathrm{(2)} \mathrm{-} \mathrm{Harsova} \mathrm{(} \mathrm{km} \mathrm{253);} \mathrm{(3)} \mathrm{-} \mathrm{Giurgiu} \mathrm{(km} \mathrm{493);}$

(4) - Bechet (km 679); (5) - Gruia (km 851); (6) - Bazias (km 1072)
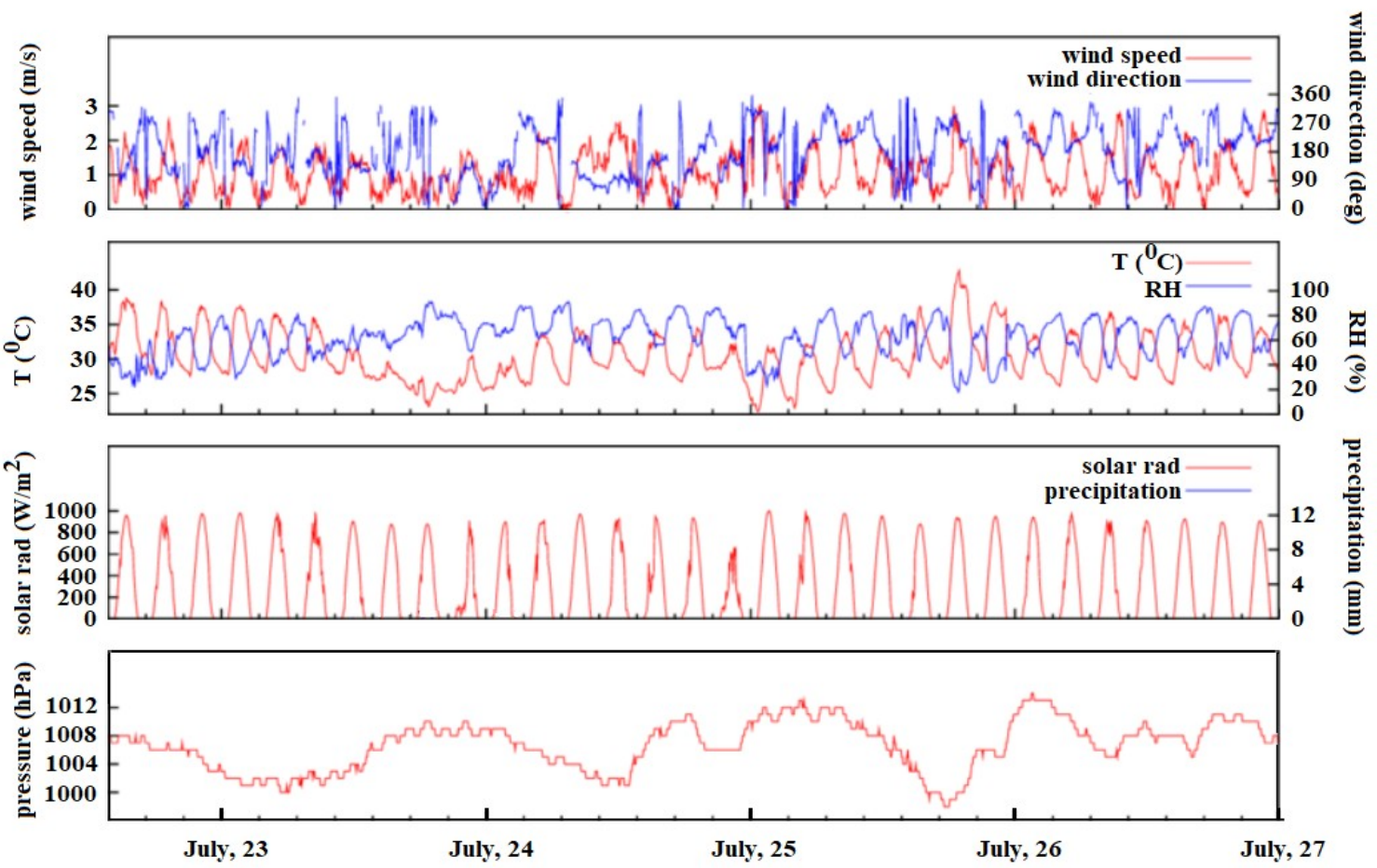

Figure 2. Meteogram - Giurgiu

(wind direction is plotted when wind speed is higher than $0.5 \mathrm{~m} / \mathrm{s}$; measurements every $30 \mathrm{~min}$ )

The temperature ranged between $23^{\circ} \mathrm{C}$ (by night) and $42^{\circ} \mathrm{C}$ (by day); also, the humidity was high, and the wind speed was below $3 \mathrm{~m} / \mathrm{s}$. The solar radiation reached extreme values, and the atmospheric pressure was slightly above the normal value. In general, the weather conditions were difficult (during that time was a Code Red Extreme Heat).
The noise was measured with BlueSolo $01 \mathrm{~dB}$ type sound meter, placed in the engine room, the main deck and the rest room, in 4 cases:
1. Idling with generator engine;
2. The ship starts from the shore;
3. The ship is running;
4. Mooring. 


\section{RESULTS AND DISCUSSIONS}

From the meteogram we can see that the weather conditions were extremely difficult, the heat and humidity from the outside, but also from the inside, reducing the working capacity of the navigators.

Following the measurements made during the entire trip, these results were obtained, as means of the experimental determinations.

Calculations were performed using
Daily Noise exposure calculator and Weekly Noise exposure calculator [6].

Exposure points will appear for each entry and the overall daily personal noise exposure $\left(\mathrm{L}_{E \mathrm{E}, \mathrm{d}}\right)$ will be displayed. The Lower Exposure Action Value (an $\mathrm{L}_{\mathrm{EP}, \mathrm{d}}$ of $80 \mathrm{~dB}$ ) is represented by 32 exposure points, the Upper Exposure Action Value ( $\mathrm{L}_{\mathrm{EP}, \mathrm{d}}$ of $85 \mathrm{~dB}$ ) by 100 points. In the first case: inside the engine room (Table 1).

Table 1

Daily Noise exposure calculator inside the engine room

\begin{tabular}{|c|c|c|c|c|}
\hline 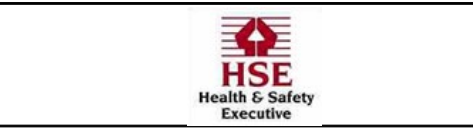 & $\begin{array}{l}\text { Noise Level } \\
\left(L_{\text {Aeq }} \text { dB }\right)\end{array}$ & $\begin{array}{c}\text { Exposure } \\
\text { duration } \\
\text { (hours) } \\
\end{array}$ & $\begin{array}{c}\text { Exposure } \\
\text { points } \\
(\text { job/task) } \\
\end{array}$ & $\begin{array}{c}\text { Exposure } \\
\text { points per } \\
\text { hour } \\
\end{array}$ \\
\hline The ship starts from the shore & 98 & 0.5 & 125 & 249 \\
\hline The ship is running & 86 & 22.5 & 354 & 16 \\
\hline Mooring & 92 & 0.5 & 31 & 63 \\
\hline Idling with generator engine & 81 & 0.5 & 2 & 5 \\
\hline & Total duration & 24 & & \\
\hline \multicolumn{2}{|c|}{ Daily noise exposure $\left(L_{E P, d}\right)$} & $92 \mathrm{~dB}$ & 512 points & \\
\hline
\end{tabular}


These calculations are different from the average, for example the arithmetic mean of the values in Table 1 is $89.25 \mathrm{~dB}$, the geometric mean is $89.0224 \mathrm{~dB}$, and the harmonic mean is $88.79875 \mathrm{~dB}$.
In the second case: on the main deck (Table 2).

In the third case: inside the rest room (Table 3).

Table 2

Daily Noise exposure calculator on the main deck

\begin{tabular}{|l|c|c|c|c|}
\hline \multicolumn{1}{|c|}{$\begin{array}{c}\text { HSE } \\
\begin{array}{c}\text { Heath \& Safety } \\
\text { Executive }\end{array}\end{array}$} & $\begin{array}{c}\text { Noise Level } \\
\left(\mathbf{L}_{\text {Aeq }} \mathbf{d B}\right)\end{array}$ & $\begin{array}{c}\text { Exposure } \\
\text { duration } \\
(\mathbf{h o u r s})\end{array}$ & $\begin{array}{c}\text { Exposure } \\
\text { points } \\
\text { (job/task) }\end{array}$ & $\begin{array}{c}\text { Exposure } \\
\text { points per } \\
\text { hour }\end{array}$ \\
\hline The ship starts from the shore & 82 & 0.5 & 3 & 6 \\
\hline The ship is running & 83 & 22.5 & 177 & 8 \\
\hline Mooring & 85 & 0.5 & 6 & 13 \\
\hline Idling with generator engine & 81 & 0.5 & 2 & 5 \\
\hline \multicolumn{2}{|r}{} \\
\hline
\end{tabular}

Table 3

Daily Noise exposure calculator inside the rest room

\begin{tabular}{|l|c|c|c|c|}
\hline \multicolumn{1}{|c|}{$\begin{array}{c}\text { Health \& Safety } \\
\text { Executive }\end{array}$} & $\begin{array}{c}\text { Noise Level } \\
\left(\mathbf{L}_{\text {Aeq }} \mathbf{d B}\right)\end{array}$ & $\begin{array}{c}\text { Exposure } \\
\text { duration } \\
\text { (hours) }\end{array}$ & $\begin{array}{c}\text { Exposure } \\
\text { points } \\
\text { (job/task) }\end{array}$ & $\begin{array}{c}\text { Exposure } \\
\text { points per } \\
\text { hour }\end{array}$ \\
\hline The ship starts from the shore & 80 & 0.5 & 2 & 4 \\
\hline The ship is running & 78 & 22.5 & 56 & 2 \\
\hline Mooring & 79 & 0.5 & 2 & 3 \\
\hline Idling with generator engine & 81 & 0.5 & 2 & 5 \\
\hline \multicolumn{2}{|}{ Daily noise exposure (LEP,d $)$} & $\mathbf{8 3 d B}$ & $\mathbf{6 2}$ points & \\
\hline
\end{tabular}

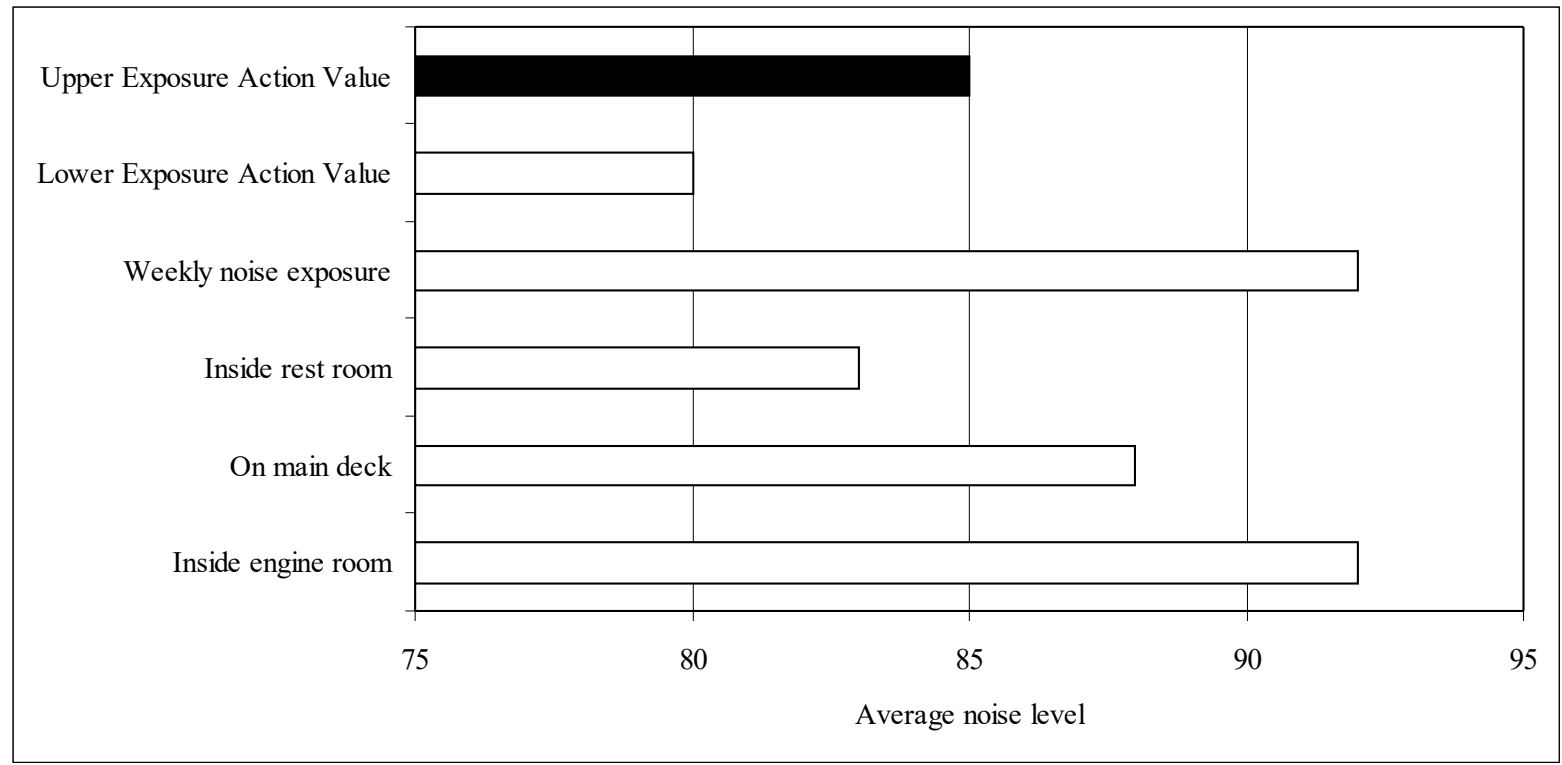

Figure 3. The sound level values for each case, compared to the allowable values indicated in Directive 2003/10/EC of the European Parliament and of the Council of 6 February 2003 on the minimum health and safety requirements regarding the exposure of workers to the risks arising from physical agents (noise) [6] 
If the calculations in Tables 1,2 and 3 are representative for a normal working day, then for the entire week, the result is presented in Table 4.

Table 4

Weekly Noise exposure calculator for the whole journey

\begin{tabular}{|c|c|}
\hline 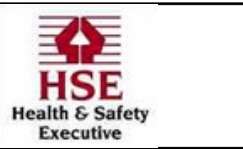 & $\begin{array}{c}\text { Daily exposure } \\
\left(L_{E P, d} d B\right)\end{array}$ \\
\hline Day 1 & 92 \\
\hline Day 2 & 87 \\
\hline Day 3 & 89 \\
\hline Day 4 & 91 \\
\hline Day 5 & 90 \\
\hline Day 6 & 94 \\
\hline $\mathbf{L}_{E P, w}$ & $92 \mathrm{~dB}$ \\
\hline
\end{tabular}

From Table 1 (noise inside the engine room) it is found that the Lower Exposure Action Value $\left(\mathrm{L}_{\mathrm{EP}, \mathrm{d}}=80 \mathrm{~dB}\right)$ is exceeded by $15 \%$ and the Upper Exposure Action Value $(85 \mathrm{~dB})$ by $8.23 \%$.

Table 2 (noise on main deck) shows that these 2 parameters are exceeded by $10 \%$ and $3.53 \%$ respectively.

Regarding the noise inside the rest room, it is seen that the Lower Exposure Action Value is exceeded by $3.75 \%$, but the sound level does not exceed the Upper Exposure Action Value.

However, if we consider the crew's exposure to noise over the entire duration of the trip, we can see that the Lower Exposure Action Value $\left(\mathrm{L}_{\mathrm{EP}, \mathrm{d}}=80 \mathrm{~dB}\right)$ is exceeded by $15 \%$ and the Upper Exposure Action Value $(85 \mathrm{~dB})$ by $8.23 \%$ (fig. 3 ).

\section{CONCLUSIONS}

It has been observed that an important part of the work of the navigators takes place outside, so the weather conditions greatly influence the comfort of the people. Unfortunately, the air conditioning inside did not compensate for this inconvenience, largely because the doors cannot be closed for a long time, but also because the equipment was outdated. They need to be replaced with new, more efficient ones.

From the experimental determinations and the analyses carried out, it is found that the crew members of this river ship are subjected to a noise that exceeds the level indicated by Directive 2003/10/EC. This leads to excessive fatigue, nervousness and can even lead to total or partial deafness. For this reason, hearing protectors are recommended.

Here is what happens if the protection is reduced by $25 \mathrm{~dB}$ for a while.
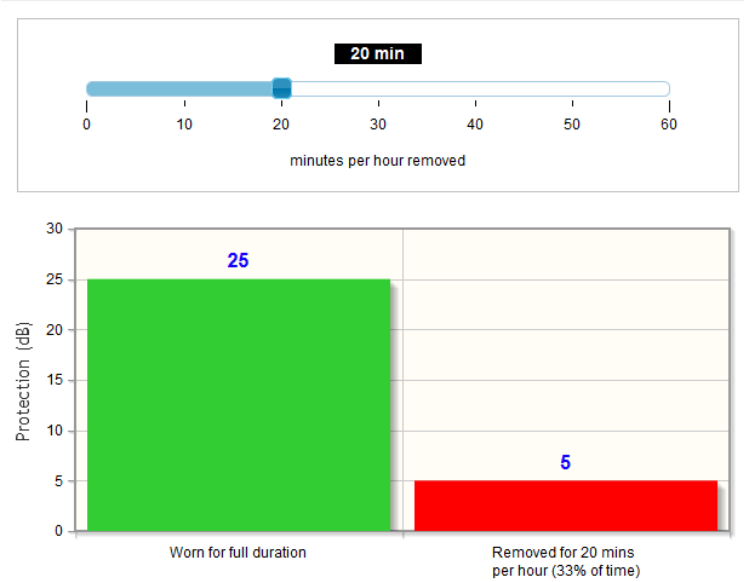

If nominal $25 \mathrm{~dB}$ protection is removed for 20 minutes, the protection reduces to $5 \mathrm{~dB}$.
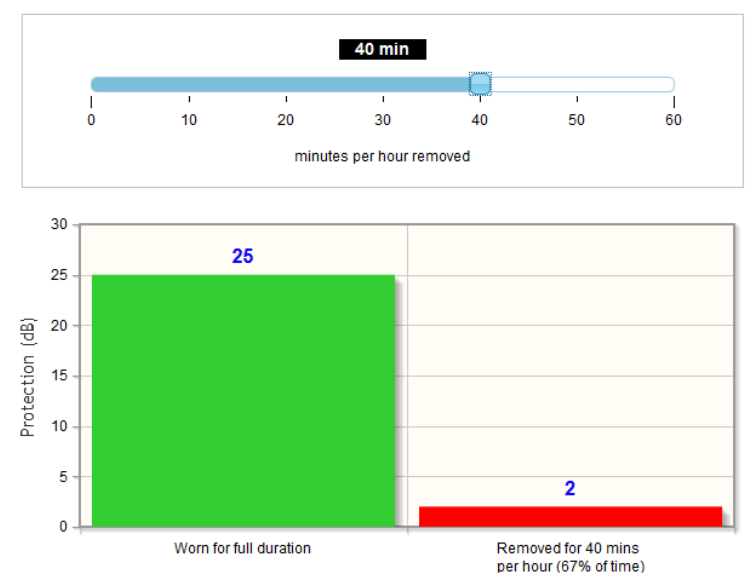

If nominal $25 \mathrm{~dB}$ protection is removed for 40 minutes, the protection reduces to $2 \mathrm{~dB}$.
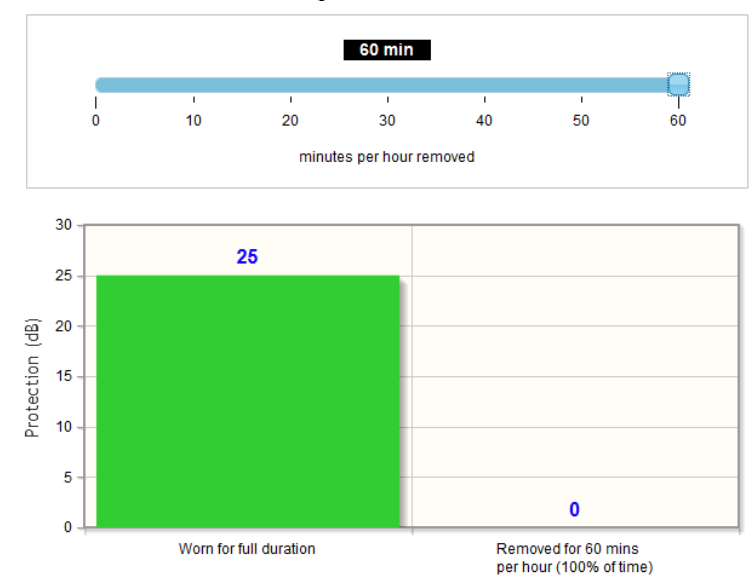

If nominal $25 \mathrm{~dB}$ protection is removed for 60 minutes, the protection reduces to $0 \mathrm{~dB}$.

Removal of hearing protectors severely reduces protection (example of nominal $25 \mathrm{~dB}$ protection).

From the Health and Safety Executive site [8], we found out regarding hearing 
protection performance. "Performance of hearing protectors is often less than the one reported on the packaging. One reason is that protectors are not worn for all of the required time. When protectors are removed in noisy areas, even for short periods, the overall protection provided is severely reduced.

This tool shows the dramatic decrease of effective protection in relation to the percentage of the time when the protection was not worn. In the example, hearing protectors with attenuation of $25 \mathrm{~dB}$ are provided for 1 hour of noisy work per day.

Expected attenuation is $25 \mathrm{~dB}$ when worn for the full 1-hour (100\% of the time).

- Remove the protectors for just 2 minutes within the hour (protectors NOT worn for $3 \%$ of the time) and the effective protection over the full 1-hour is reduced to the equivalent hearing protectors with an attenuation of just $14 \mathrm{~dB}$.

Any hearing protector worn for half of the time required will give no more than $3 \mathrm{~dB}$ of effective protection, irrespective of its protection rating.

Employers can improve the protection gained from hearing protection by:

Providing a range of suitable hearing protection from which employees can select a model that fits them well and they can use comfortably for the time required;

Helping employees communicate without removing hearing protection in noisy areas (by providing quiet areas or protectors with communication facilities); and

- Ensuring, through training and supervision, that protection is in good condition and is worn at all times in areas where it is required.

Employees have a duty to make full use of hearing protectors which have been provided to them".

These people work twelve-hour shifts, although the law stipulates only $8 \mathrm{~h}$ of work. For these reasons, adding that they have an erratic life in which alcohol is just one of the negative factors, immediate action should be taken to ensure that these people do not become ill in the shortest possible time

\section{REFERENCES}

[1] Picu, L., Picu, M., Rusu, E.V.C., An Investigation into the Health Risks Associated with the Noise and Vibrations on Board of a Boat - A Case Study on the Danube River, Journal of Marine Science and Engineering (JMSE), 2019, Volume 7, Issue 8, Paper ID 258, pp 1-15, EISSN 2077-1312, DOI https://doi.org/10.3390/jmse7080258.

[2] Picu L., Rusu E.V.C., Picu M., An analysis of the noise in the engine room - case study a merchant ship navigating on Danube, The $19^{\text {th }}$ International Multidisciplinary Scientific GeoConference (SGEM 2019), 28 June-7 July 2019, Albena, Bulgaria, Conference Proceedings Vol. 19, Issue: 5.2, pp 6975, DOI: https://doi.org/10.5593/sgem2019/5.2/S20.055.

[3] Picu L., Picu M., Rusu E.V.C., Noise analysis on the navigation bridge for a boat traveling on the Danube River, The $19^{\text {th }}$ International Multidisciplinary Scientific GeoConference (SGEM 2019), 28 June-7 July 2019, Albena, Bulgaria, Conference Proceedings Vol. 19, Issue: 5.2, pp 571578, DOI: https://doi.org/10.5593/sgem2019/5.2/S20.055.

[4] Lloyd's Register, Ship Vibration and Noise Guidance Notes, Section 8 (Noise), 2006.

[5] Lloyd's Register, Guidance Notes General Overview of Ship Structural Vibration and Noise Problems, September 2015.

[6] Health and Safety Executive, Exposure calculators, HTTP://WWW.HSE.GOV.UK/NOISE/CALCULATOR. $\underline{\text { HTM }}$

[7] Directive 2003/10/EC of the European Parliament and of the Council of 6 February 2003 on the minimum health and safety requirements regarding the exposure of workers to the risks arising from physical agents (noise) HTTPS://EURLEX.EUROPA.EU/LEXURISERV/LEXURISERV.DO? URI=OJ:L:2003:042:0038:0044:EN:PDF

[8] Health and Safety Executive, Removal of hearing protectors severely reduces protection,

http://www.hse.gov.uk/noise/hearingprotection/index.htm 